\title{
Poemas de Robert Frost
}

Traduzidos por Dirlen Loyolla 
STOPPING BY WOODS

ON A SNOWY EVENING

\section{(Robert Frost)}

Whose woods these are I think I know. His house is in the village, though; He will not see me stopping here To watch his woods fill up with snow. My little horse must think it queer To stop without a farmhouse near Between the woods and frozen lake The darkest evening of the year. He gives his harness bells a shake To ask if there is some mistake. The only other sound's the sweep Of easy wind and downy flake. The woods are lovely, dark and deep, But I have promises to keep, And miles to go before I sleep, And miles to go before I sleep.

\section{PUTTING IN THE SEED (Robert Frost)}

You come to fetch me from my work to-night When supper's on the table, and we'll see If I can leave off burying the white Soft petals fallen from the apple tree (Soft petals, yes, but not so barren quite, Mingled with these, smooth bean and wrinkled pea); And go along with you ere you lose sight Of what you came for and become like me, Slave to a Springtime passion for the earth. How Love burns through the Putting in the Seed On through the watching for that early birth When, just as the soil tarnishes with weed, The sturdy seedling with arched body comes Shouldering its way and shedding the earth crumbs.

\section{FIRE AND ICE}

$$
\text { (Robert Frost) }
$$

Some say the world will end in fire, Some say in ice.

From what I've tasted of desire I hold with those who favor fire.

But if it had to perish twice,

I think I know enough of hate

To say that for destruction ice

Is also great

And would suffice.

\section{À BEIRA DA MATA NUMA NOITE DE NEVE}

\section{(Tradução de Dirlen Loyolla)}

Sei quem é o dono dessa mata, por certo Mora na cidade e não aqui por perto; Não terá então como me ver neste lugar A olhar seu bosque totalmente coberto. O meu cavalo começa a estranhar Assim, parado, no meio do mato ficar Entre as árvores nevadas e o lago gelado $\mathrm{Na}$ noite mais densa do ano a findar. Ele chacoalha os sinos dos arreios, agitado Como se a mim perguntasse se há algo errado. O outro único som que conseguimos ouvir É o dos flocos caindo e do vento soprado. O bosque é imenso, adorável, treva a sorrir. Mas ainda tenho promessas a cumprir, E muito chão para correr antes de dormir, E muito chão para correr antes de dormir.

\section{SEMEANDO (Tradução de Dirlen Loyolla)}

Vens me tirar de meu noturno ofício À hora certa do jantar; mas, verás, Não poderás impedir-me o vício De enterrar, da macieira, as pétalas (simples pétalas, sim, mas não sozinhas, misturadas que estão ao feijão e ao milho) $E$ te fazer esquecer o que te traz Aqui e te tornar, assim, tão isso, Similar a mim, amante da terra. Sim, o Amor está no semear e nisso De esperar e ver brotar aquelas Que vão manchar, daninhas, o solo difícil $\mathrm{Da}$ arqueada e forte muda, pequena dona De ombros que empurram as coisas da terra.

\section{FOGO E GELO}

(Tradução de Dirlen Loyolla)

Uns dizem que o mundo em fogo termina, Outros, que em gelo se apaga.

E eu já provei de desejo, que é sina Por isso repito que em fogo termina. Mas se mais uma vez nosso mundo se estraga, Só sei que na vida provei tanto ódio voraz Que posso dizer que, se em gelo se apaga, Tanto fez como tanto faz, Posto que tudo se acaba. 